\title{
Influence of cortisol on adipose tissue development in the fetal sheep during late gestation
}

\author{
A Mostyn, S Pearce, H Budge, M Elmes, A J Forhead', \\ A L Fowden', T Stephenson and M E Symonds \\ Academic Division of Child Health, School of Human Development, Queen's Medical Centre, University Hospital, Nottingham NG7 2UH, UK \\ ${ }^{1}$ Department of Physiology, University of Cambridge, Downing Site, Cambridge CB2 3EG, UK \\ (Requests for offprints should be addressed to M E Symonds; Email: Michael.Symonds@nottingham.ac.uk) \\ (M Elmes is now at Reproduction and Development Group, Department of Veterinary Basic Sciences, The Royal Veterinary College, Potters Bar, \\ Hertfordshire AL9 7TA, UK)
}

\begin{abstract}
The present study examined the extent to which the late gestation rise in fetal plasma cortisol influenced adipose tissue development in the fetus. The effect of cortisol on the abundance of adipose tissue mitochondrial proteins on both the inner (i.e. uncoupling protein (UCP)1) and outer (i.e. voltage-dependent anion channel (VDAC)) mitochondrial membrane, together with the long and short forms of the prolactin receptor (PRLR) protein and leptin mRNA was determined. Perirenal adipose tissue was sampled from ovine fetuses to which (i) cortisol (2-3 mg/ day for 5 days) or saline was infused up to 127-130 days of gestation, and (ii) adrenalectomised and intact controls at between 142 and 145 days of gestation (term $=148$ days). UCP1 protein abundance was significantly lower in adrenalectomised fetuses compared with age-matched controls, and UCP1 was increased by cortisol infusion and with gestational age. Adrenalectomy reduced the concentration of the long form of PRLR, although this effect was
\end{abstract}

only significant for the highest molecular weight isoform. In contrast, neither the short form of PRLR, VDAC protein abundance or leptin mRNA expression was significantly affected by gestational age or cortisol status. Fetal plasma triiodothyronine concentrations were increased by cortisol and with gestational age, an affect abolished by adrenalectomy. When all treatment groups were combined, both plasma cortisol and triiodothyronine concentrations were positively correlated with UCP1 protein abundance. In conclusion, an intact adrenal is necessary for the late gestation rise in UCP1 protein abundance but cortisol does not appear to have a major stimulatory role in promoting leptin expression in fetal adipose tissue. It remains to be established whether effects on UCP1 protein are directly regulated by cortisol alone or mediated by other anabolic fetal hormones such as triiodothyronine. Journal of Endocrinology (2003) 176, 23-30

\section{Introduction}

At birth, the neonate is exposed to low ambient temperatures for the first time and, depending on its maturity, may need to rapidly produce heat in order to prevent hypothermia. In newborn sheep, which are precocial offspring and therefore comparable to some extent to human infants, the rapid recruitment of non-shivering thermogenesis in brown adipose tissue is critical in the prevention of hypothermia (Clarke et al. 1997c). This effect is mediated by the large increase in amount and thermogenic potential of the brown adipose tissue-specific uncoupling protein (UCP)1 (Clarke et al. 1997a). Outer mitochondrial membrane proteins, such as the voltage-dependent anion channel (VDAC), may also influence brown adipose tissue function by regulating the supply of mitochondrial ATP and ADP (Gottlieb 2000).
In sheep, the abundance of UCP1 and VDAC in brown adipocytes is maximal at birth and then declines over the first month of postnatal life (Clarke et al. 1997b, Mostyn et al. 2001), concomitant with a switch from non-shivering to shivering thermogenesis as the primary mechanism of heat production (Symonds et al. 1989). During the perinatal period, thermogenic potential and UCP1 expression are upregulated by a number of hormones including noradrenaline, triiodothyronine $\left(\mathrm{T}_{3}\right)$, prolactin and leptin (Symonds et al. 2000, Evens et al. 2001, Budge et al. 2002). Consequently, the abundance of the receptors for these hormones, and the synthesis of leptin itself, in brown adipose tissue may also affect the function and abundance of UCP1 in the neonate.

In many tissues, the maturational changes essential for neonatal survival begin before birth and are dependent on the normal increase in plasma glucocorticoid concentration 
in the fetus towards term (Liggins 1994). Cortisol has been shown to affect the expression of a wide range of proteins during the prepartum period including enzymes, hormones, binding proteins and receptors (Fowden et al. 1998). In sheep, the prepartum cortisol surge upregulates expression of prolactin receptors (PRLRs) in the fetal liver which coincides with the increase in hepatic $5^{\prime}$ monodeiodinase activity (Clarke et al. 1997a, Phillips et al. 1997). As a consequence of increased deiodination of thyroxine $\left(T_{4}\right)$ to $T_{3}$, the circulating $T_{3}$ concentration in the fetus also increases towards term (Fraser \& Liggins 1989). In fetal sheep, there is a gradual increase in brown adipose tissue mitochondrial protein content and GDP binding during late gestation (Clarke et al. 1997a), which closely parallels the fetal cortisol surge towards term (Fowden et al. 1998). In addition, maternal administration of the synthetic glucocorticoid, dexamethasone, for 2 days in the week before full term enhances UCP1 abundance in perirenal adipose tissue from prematurely delivered sheep (Clarke et al. 1998). This occurs in conjunction with an increase in the short, but not the long form of the PRLR (Bispham et al. 1999). However, the role of cortisol in brown adipose tissue maturation and the developmental expression of UCP1 remains unknown. Hence, this study examined the hypothesis that fetal cortisol has a primary role in promoting fetal adipose tissue maturation in preparation for life after birth. This was examined by determining the effect of (i) infusing cortisol into the fetus between 122 and 125 days of gestation in order to increase fetal plasma cortisol to values observed near to term and (ii) removing the adrenal, thereby reducing fetal plasma cortisol to basal values. Effects on fetal adipose tissue maturation were then compared with age-matched controls with respect to the abundance of mitochondrial proteins (UCP1 and VDAC), PRLR and leptin in perirenal adipose tissue (which constitutes up to $80 \%$ of fetal adipose tissue).

\section{Materials and Methods}

\section{Animals}

A total of 27 Welsh Mountain sheep fetuses of known gestational age were used in this study. Ten were twin lambs and the remainder were singletons. In the case of twins only one twin was used in the study. The ewes were housed in individual pens from and maintained on $200 \mathrm{~g} /$ day concentrates, with free access to hay, water and a salt-lick block from 100 days of gestation. All animals were fed daily at $\sim 0900 \mathrm{~h}$. Food but not water was witheld for 18-24 h before surgery. The study aimed to determine the effect of (i) a precious rise in fetal cortisol and (ii) a prolonged reduction in fetal cortisol. The first objective was achieved by comparing the effect of a 5-day period of cortisol infusion sufficient to double its plasma concentration up to 127-130 days of gestation. Effects on adipose tissue maturation were then compared with agematched fetuses into which saline had been infused. The second objective was achieved by surgically removing the fetal adrenal between 115 and 119 days of gestation, thereby preventing any prepartum rise in fetal cortisol and then comparing adipose tissue composition with nonoperated age-matched fetuses near to term, i.e. 142-145 days of gestation, with term being 148 days of gestation. We have previously shown no difference in adipose tissue composition in neonatal lambs between those which have undergone a sham operation and those not subjected to this procedure (Schermer et al. 1996). All procedures were carried out under the UK Animal (Scientific Procedures) Act 1986.

\section{Surgical procedures}

Between 115 and 118 days (term $145 \pm 2$ days), one of the following procedures was carried out under halothane anaesthesia $\left(1.5 \%\right.$ in $\left.\mathrm{O}_{2} / \mathrm{N}_{2} \mathrm{O}\right)$ using the surgical methods described previously (Fowden et al. 1996): (i) intravascular catheterisation of the fetus $(n=15)$ or (ii) bilateral adrenalectomy of the fetus $(n=6)$. Catheters were inserted into the aorta of the mother and the dorsal aorta and caudal vena cava of the fetus via the femoral vessels. At the end of surgery the fetuses were given $100 \mathrm{mg}$ ampicillin (Penbritin; Beecham Animal Health, Brentford, UK) either i.v. or intra-amniotically. The ewes received antibiotic i.m. (1 g procaine penicillin (Depocillin; Mycofarm, Cambridge, UK)) on the day of surgery and for 3 days thereafter. Apart from the pre-surgery period of food withdrawal there were no apparent differences between operated and non-operated animals with respect to feeding patterns.

\section{Experimental procedure}

Blood samples of $2 \mathrm{ml}$ were taken daily throughout the experimental period from all the catheterised fetuses to monitor fetal well-being and to determine plasma cortisol and thyroid hormone concentrations. At least 6 days after catheterisation, 13 fetuses were infused with either cortisol $(n=8,2-3 \mathrm{mg} /$ day in $3 \mathrm{ml} 0.9 \%(\mathrm{w} / \mathrm{v})$ saline (EFCortelan; Glaxo Ltd, Greenford, Middlesex, UK)) or saline $(n=7,3 \mathrm{ml} /$ day, $0.9 \% \mathrm{w} / \mathrm{v})$ for 5 days before tissue collection at 127-130 days. The fetuses to be given cortisol were selected randomly. The dose of cortisol was chosen to produce concentrations of plasma cortisol similar to those observed close to term, i.e. $40-50 \mathrm{ng} / \mathrm{ml}$ (Fowden et al. 1996). There was no difference in the distribution of male and female fetuses between treatment groups or any effect of gender on plasma cortisol.

\section{Sample collection}

All operated fetuses, regardless of treatment, and six additional non-operated intact fetuses were delivered by 
Caesarean section under sodium pentobarbitone anaesthesia $(20 \mathrm{mg} / \mathrm{kg}$ i.v.) between 127 and 130 days of gestation for cortisol- and saline-infused fetuses and between 142 and 145 days for adrenalectomised (AX) and control fetuses. Fetal blood samples were taken at the time of delivery either through the indwelling arterial catheter or by venipuncture from the umbilical artery in the cord. After administration of a lethal dose of anaesthetic (200 mg/kg sodium pentobarbitone), samples of perirenal adipose tissue were collected and frozen rapidly in liquid nitrogen before storage at $-80{ }^{\circ} \mathrm{C}$. All blood samples were centrifuged immediately at $4{ }^{\circ} \mathrm{C}$ and the plasma stored at $-20{ }^{\circ} \mathrm{C}$ before plasma analyses. No adrenal remnants were found in any of the AX fetuses at autopsy.

\section{Laboratory analyses}

Protein immunodetection Crude plasma membranes or mitochondria were prepared from $1 \mathrm{~g}$ frozen adipose tissue as described previously (Budge et al. 2000) and the protein content of each preparation was determined (Lowry et al. 1951). The thermogenic potential of mitochondria was determined using $\left[{ }^{3} \mathrm{H}\right] \mathrm{GDP}$, which measures the specific binding of GDP to UCP1 in mitochondrial preparations at a physiological concentration of $2 \mu \mathrm{M}$ (Symonds et al. 1992). PRLR abundance in plasma membranes was detected using $6 \mu \mathrm{g}$ protein, following protein separation by SDS-PAGE, immunoblotting and enhanced chemiluminesence (Amersham International) (Budge et al. 2000) utilising polyclonal antibodies R122 and R133 described by Nevalainen et al. (1996), which are specific for the long and short forms of PRLR respectively. These antibodies do detect a range of different molecular mass isoforms of each form of the receptor that are tissue-specific and have been interpreted as representing separate extracellular domains of the receptor (Nevalainen et al. 1996, Budge et al. 2000). UCP1 content in perirenal adipose tissue was measured as described by Schermer et al. (1996). VDAC abundance was determined using an antibody raised in rabbits to ovine VDAC (Budge et al. 2002) purified from the kidney of a newborn lamb based on the method of Schermer et al. (1996) as described for UCP1 and was used at a dilution of 1 in 2000. Densitometric analysis was performed on each gel and all values were expressed in densitometric units. Specificity of detection was confirmed using non-immune rabbit serum. A range of molecular mass markers was included on all gels. Densitometric analysis was performed on each membrane following image detection using a Fujifilm LAS-1000 cooled charge-coupled device camera (Fuji Photo Film Co. Ltd, Tokyo, Japan). All gels were run in duplicate and a reference sample (i.e. 4-hour-old lamb born vaginally at term) was included on each.

mRNA detection Total RNA was isolated from perirenal adipose tissue using Tri-Reagent (Sigma). In order to maximise sensitivity, a two-tube approach to reverse transcription (RT) was adopted. The conditions used to generate first-strand cDNA RT were: $70{ }^{\circ} \mathrm{C}(5 \mathrm{~min}), 4{ }^{\circ} \mathrm{C}$ $(5 \mathrm{~min}), 25^{\circ} \mathrm{C}(5 \mathrm{~min}), 25^{\circ} \mathrm{C}(10 \mathrm{~min}), 42{ }^{\circ} \mathrm{C}(1 \mathrm{~h})$, $72{ }^{\circ} \mathrm{C}(10 \mathrm{~min}), 4{ }^{\circ} \mathrm{C}(5 \mathrm{~min})$. The $\mathrm{RT}$ reaction (final volume $20 \mu \mathrm{l}$ ) contained: $5 \times$ cDNA (first-strand), buffer $\left(250 \mathrm{mM}\right.$ Tris- $\mathrm{HCl}, 40 \mathrm{mM} \mathrm{MgCl}_{2}, 150 \mathrm{mM} \mathrm{KCl}$, $5 \mathrm{mM}$ dithioerythritol $\mathrm{pH} 8 \cdot 5), 2 \mathrm{mM}$ dNTPs, $1 \times$ hexanucleotide mix, 10 units RNase inhibitor, 10 units M-MLV reverse transcriptase and $1 \mu \mathrm{g}$ total RNA. All these commercially available products were purchased from Roche.

The expression of mRNA for leptin was determined as described by Bispham et al. (2002). The analysis utilised the following cDNA primers to the ovine leptin gene: 5'-CAC CAA AAC CCT CAT CAA GAC G-3' (27-58) and 5'-ACA TTT CTG GAA GGC AGA CTG G-3' (197-228, Genbank U84247), which generated a 192 bp intron spanning product. QuantumRNA alternate 18S internal standards (Ambion, Abingdon, Oxon, UK) were included in the multiplex PCRs. Briefly, the incubation conditions were: $94{ }^{\circ} \mathrm{C}(2 \mathrm{~min}) 1$ cycle; $94{ }^{\circ} \mathrm{C}(30 \mathrm{~s})$, $60{ }^{\circ} \mathrm{C}(30 \mathrm{~s}), 72{ }^{\circ} \mathrm{C}(1 \mathrm{~min}) 30$ cycles; $72{ }^{\circ} \mathrm{C}(7 \mathrm{~min}) 1$ cycle. The PCR mixture (final volume $20 \mu \mathrm{l}$ ) contained: $10 \times$ PCR buffer $\left(100 \mathrm{mM}\right.$ Tris- $\mathrm{HCl}, 15 \mathrm{mM} \mathrm{MgCl}_{2}$, $500 \mathrm{mM} \mathrm{KCl} \mathrm{pH} \mathrm{8 \cdot 3),} 500 \mu \mathrm{M}$ dNTPs, $1 \mathrm{mM}$ each leptin primer, $3.75 \mathrm{U}$ Taq polymerase. Agarose gel electrophoresis $(2 \cdot 0 \%)$ and ethidium bromide staining confirmed the presence of both leptin and $18 \mathrm{~S}$ products of the expected sizes. UCP1 mRNA abundance was determined as described by Mostyn et al. (2002) with densitometric analysis performed as described for UCP1 protein above. Consistency of lane loading for each sample was verified by hybridisation with the $18 \mathrm{~S}$ rRNA oligo-probe and all results were expressed as a ratio of UCP1 to $\mathrm{r} 18 \mathrm{~S}$ abundance. All analyses and gels were conducted in duplicate.

RIAs Cortisol concentrations were measured by RIA and validated for use with ovine plasma (Robinson et al. 1983). The minimum detectable quantity of cortisol was $1.5 \mathrm{ng} /$ $\mathrm{ml}$ and interassay coefficient of variation was $11 \%$. Total plasma $T_{3}$ and $T_{4}$ concentrations were also measured by RIA, using a commercial kit (ICN Biomedicals, Thame, Oxon, UK) validated for ovine plasma (Fowden et al. 1983). The lower units of detection were $0 \cdot 1 \mathrm{ng} / \mathrm{ml}$ for $\mathrm{T}_{3}$ and $7 \mathrm{ng} / \mathrm{ml}$ for $\mathrm{T}_{4}$. The interassay coefficient of variation was $10 \%$ for both assays.

\section{Statistical analyses}

Statistical analysis with respect to significant differences $(P<0 \cdot 05)$ between mean values obtained between treatment groups was carried out using Mann-Whitney $U$ tests. Regression analysis between UCP1, cortisol and $\mathrm{T}_{3}$ was carried out using SPSS. 
Table 1 Effect of cortisol infusion, adrenalectomy (AX) and gestational age on plasma concentrations of cortisol, $\mathrm{T}_{3}, \mathrm{~T}_{4}$ and thermogenic potential (GDP binding), VDAC protein and leptin mRNA abundance in perirenal adipose tissue of the ovine fetus. Values are means \pm S.E. with numbers of animals in each group given in parentheses

\begin{tabular}{|c|c|c|c|c|c|c|c|}
\hline & Treatment & $\begin{array}{l}\text { Plasma cortisol } \\
(\mathrm{ng} / \mathrm{ml})\end{array}$ & $\begin{array}{l}\text { Plasma }_{(\mathrm{ng} / \mathrm{ml})} \\
\text { Pl }\end{array}$ & $\begin{array}{l}\text { Plasma }_{(\mathrm{ng} / \mathrm{ml})} \\
\text { Pl }\end{array}$ & $\begin{array}{l}\text { GDP binding } \\
(\mu \mathrm{mol} \text { GDP } / \\
\text { mg MP) }\end{array}$ & $\begin{array}{l}\text { VDAC } \\
\text { (\% ref.) }\end{array}$ & $\begin{array}{l}\text { Leptin mRNA } \\
\text { (\% of } 18 \mathrm{~S} \text { ) }\end{array}$ \\
\hline \multicolumn{8}{|c|}{$\begin{array}{l}\text { Gestational } \\
\text { age (days) }\end{array}$} \\
\hline \multirow[t]{2}{*}{$127-130$} & Saline & $\begin{array}{l}14 \cdot 0 \pm 2 \cdot 3 \\
(7)\end{array}$ & $\begin{array}{l}0 \cdot 28 \pm 0 \cdot 04 \\
(7)\end{array}$ & $\begin{array}{l}76 \cdot 4 \pm 4 \cdot 3 \\
(7)\end{array}$ & $\begin{array}{l}16 \cdot 3 \pm 1 \cdot 3 \\
(5)\end{array}$ & $\begin{array}{l}90 \cdot 3 \pm 6 \cdot 8 \\
(5)\end{array}$ & $\begin{array}{l}2 \cdot 3 \pm 1 \cdot 4 \\
(5)\end{array}$ \\
\hline & Cortisol & $\begin{array}{l}45 \cdot 7 \pm 5 \cdot 3^{*} \\
(8)\end{array}$ & $\begin{array}{l}0 \cdot 57 \pm 0 \cdot 16^{*} \\
(5)\end{array}$ & $\begin{array}{l}64 \cdot 1 \pm 4 \cdot 3 \\
(6)\end{array}$ & $\begin{array}{l}35 \cdot 1 \pm 11 \cdot 9 \\
(5)\end{array}$ & $\begin{array}{l}104 \cdot 7 \pm 3 \cdot 7 \\
\text { (5) }\end{array}$ & $\begin{array}{l}4 \cdot 4 \pm 2 \cdot 2 \\
(5)\end{array}$ \\
\hline $142-145$ & $A X$ & $\begin{array}{l}7 \cdot 2 \pm 0 \cdot 06^{*} \\
(6)\end{array}$ & $\begin{array}{l}0 \cdot 29 \pm 0 \cdot 04^{*} \\
(6)\end{array}$ & $\begin{array}{l}82 \cdot 1 \pm 5 \cdot 6 \\
(6)\end{array}$ & $\begin{array}{l}18 \cdot 2 \pm 2 \cdot 3 \\
(6)\end{array}$ & $\begin{array}{l}72 \cdot 5 \pm 9 \cdot 2 \\
(6)\end{array}$ & $\begin{array}{l}1 \cdot 9 \pm 0 \cdot 3 \\
(6)\end{array}$ \\
\hline
\end{tabular}

ref. =4-hour-old newborn lamb; MP= mitochondrial protein.

*Significantly different from the corresponding control group, $P<0 \cdot 05$.

${ }^{\dagger}$ Significantly different from the value in the control group at $127-130$ days, $P<0.05$.

\section{Results}

\section{Ontogenic development of fetal perirenal adipose tissue}

The fetal concentrations of plasma cortisol and $\mathrm{T}_{3}$ were significantly higher close to term (142-145 days) than earlier in gestation (Table 1). This occurred in the absence of any significant changes in $T_{4}$. At 142-145 days, abundance of UCP1 protein, but not mRNA, in perirenal adipose tissue was significantly higher than at 127130 days (Fig. 1). In contrast to UCP1 protein, there was no change in GDP binding to mitochondria from perirenal adipose tissue with increasing age (Table 1). There was a non-significant trend for mean GDP binding to be increased by cortisol infusion. Gestational age had no effect on VDAC protein, leptin mRNA (Table 1) or protein abundance for either form of PRLR (Fig. 2). Fetal weight was not significantly different between the two treatment groups at each gestational age (data not shown).

\section{Effects of manipulating the fetal cortisol concentrations on perirenal adipose tissue}

Fetal adrenalectomy Removal of the fetal adrenal gland prevented the normal rise in fetal plasma concentrations of cortisol and $\mathrm{T}_{3}$ towards term: mean values of plasma cortisol and $T_{3}$ in the AX fetuses at 142-145 days were significantly less than those seen in intact controls at the same gestational age (Table 1). Fetal adrenalectomy also prevented the prepartum rise in UCP1 protein abundance in the perirenal adipose tissue (Fig. 1a). At 142-145 days, mean UCP1 protein abundance in the AX fetuses was significantly less than in the control fetuses at the same gestational age and was similar to that seen earlier in gestation. Abundance of UCP1 mRNA also tended to be less in AX than in control fetuses close to term but this difference was not statistically significant (Fig. 1b). Fetal adrenalectomy had no effect on mRNA abundance for leptin or VDAC protein (Table 1). However, it did reduce expression of the long form of PRLR compared with the control fetuses close to term, although this effect was only significant for the $52 \mathrm{kDa}$ isoform (Fig. 2a). No effect was observed for the short form of PRLR (Fig. 2b).

Fetal cortisol infusion Infusion of cortisol into immature fetuses raised fetal plasma concentrations of cortisol and $\mathrm{T}_{3}$ (Table 1). Mean values of plasma cortisol and $\mathrm{T}_{3}$ were significantly higher in cortisol-infused fetuses than in the saline-infused controls at 127-130 days (Table 1). UCP1 protein, but not mRNA abundance, was similarly increased by cortisol infusion (Fig. 1). Fetal cortisol infusion had no effect on the protein abundance for VDAC or prolactin receptor (Fig. 2) or leptin gene in the perirenal adipose tissue.

\section{Relationship between UCP1 protein abundance and plasma concentrations of cortisol and $T_{3}$}

Since UCP1 protein abundance was elevated when cortisol and $\mathrm{T}_{3}$ levels were raised and were low when cortisol and $\mathrm{T}_{3}$ were low, the relationship between UCP1 protein abundance in perirenal adipose tissue and the plasma concentrations of these hormones was examined in more detail. When individual results from all fetuses were combined regardless of gestational age or treatment, the plasma concentration of $\mathrm{T}_{3}$ was significantly correlated to plasma cortisol (Fig. 3). In addition, there was a significant positive correlation between UCP1 protein abundance in perirenal adipose tissue and both the plasma concentrations of cortisol and $\mathrm{T}_{3}$ (Fig. 4). Multiple regression analysis of the three variables gave standardised beta coefficients of 
(a)

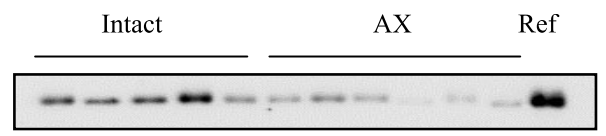

UCP1

$32 \mathrm{kDa}$

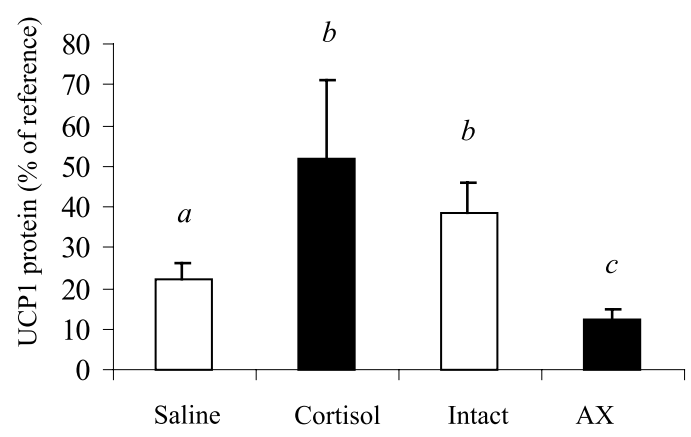

(b) (a)
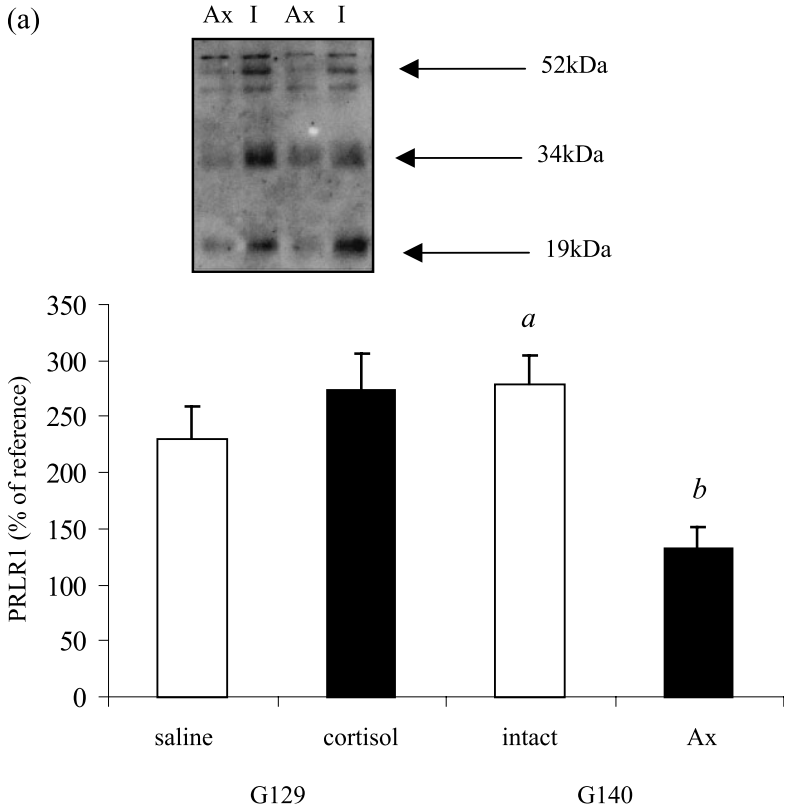

(b)

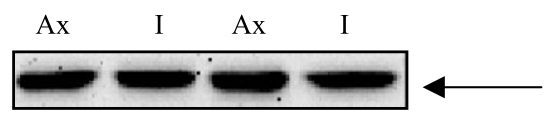

$50 \mathrm{kDa}$

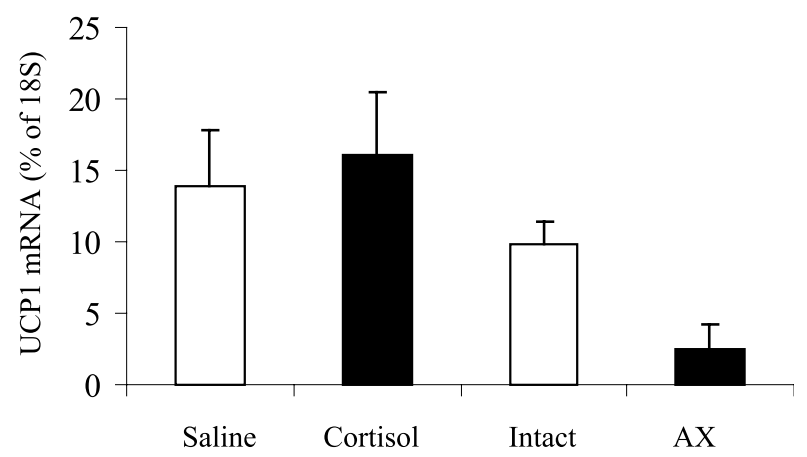

G129

Figure 1 Effect of cortisol infusion, adrenalectomy (AX) and gestational age on uncoupling protein $(\mathrm{UCP}) 1$ (a) protein and (b) mRNA in fetal perirenal adipose tissue. Examples of a charge-coupled device camera image showing the effect of adrenalectomy on (a) UCP1 protein and (b) UCP1 mRNA in individual fetuses sampled between 142 and 145 days of gestation are also shown. Values are means with their S.E. values and $n=4-6$ per group. $\mathrm{G}=$ mean gestational age. $R e f=$ reference sample, i.e. adipose tissue sampled from a 4-hour-old lamb born vaginally. Significant differences with gestational age or treatment group: $a$ vs $b, P<0.05 ; a$ vs $c P<0.01$.

0.328 and 0.448 for $\mathrm{T}_{3}$ and cortisol respectively, indicating similar effects of each hormone with respect to their potential regulation of UCP1 protein.

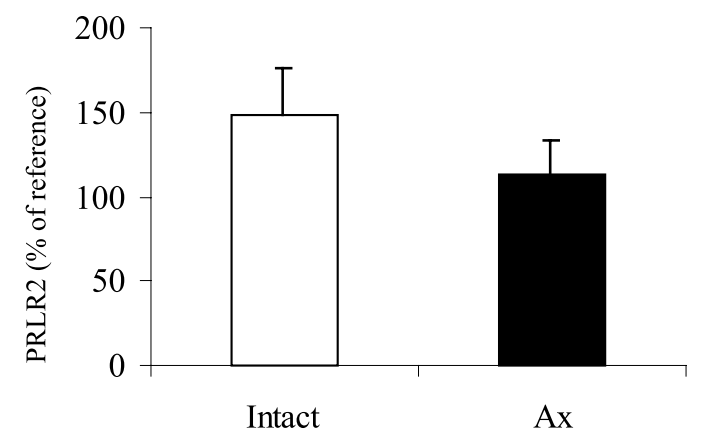

G140

Figure 2 Effect of cortisol infusion, adrenalectomy (Ax) and gestational age on the abundance of the (a) long (PRLR1, $52 \mathrm{kDa}$ isoform) and (b) short forms (PRLR2) of prolactin receptor in fetal perirenal adipose tissue. Examples of a charge-coupled device camera image showing the effect of adrenalectomy on each specific isoform for (a) the long form of PRLR protein (see Methods) and (b) the short form or PRLR in individual fetuses sampled between 142 and 145 days of gestation are shown. $\mathrm{G}=$ mean gestational age. I=intact. Values are means with their S.E. values and $n=4-6$ per group. Significant differences between treatment groups: $a$ vs $b P<0 \cdot 01$.

\section{Discussion}

The major finding of the present study is that, in fetal sheep, cortisol regulates the level of the brown adipose 


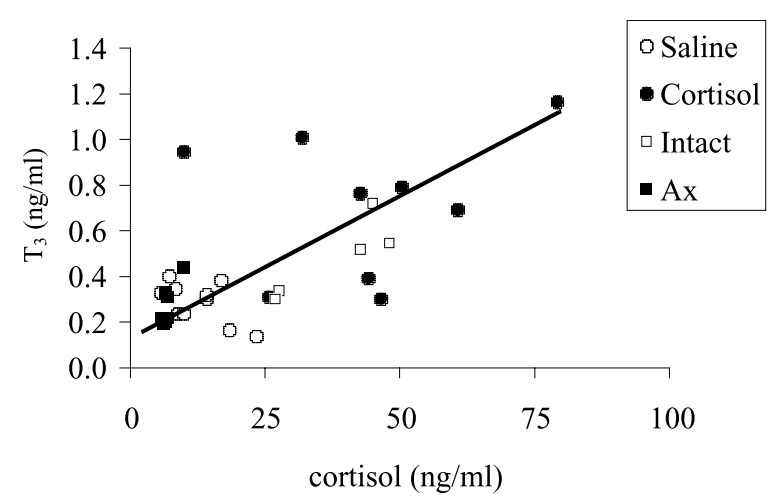

Figure 3 Positive relationship between plasma cortisol and $T_{3}$ concentrations in all fetuses irrespective of treatment or gestational age. $R^{2}=0.595, P=0 \cdot 001$, where $y=0 \cdot 01 x+0 \cdot 18$.
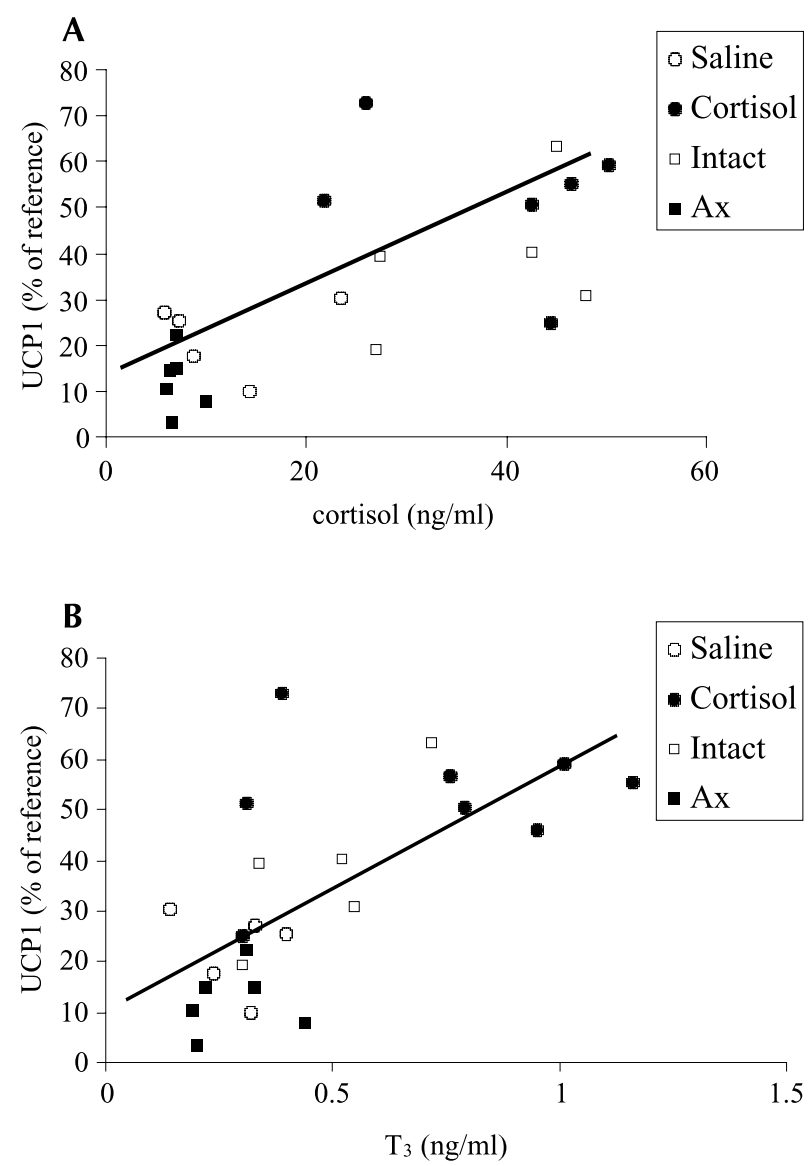

Figure 4 Positive relationship between uncoupling protein (UCP) 1 abundance and plasma concentrations of $(\mathrm{A})$ cortisol $\left(R^{2}=0 \cdot 48\right.$, $P<0 \cdot 001$, where $y=0 \cdot 66 x+14 \cdot 78)$ and $(B) T_{3}\left(R^{2}=0 \cdot 44, P<0 \cdot 001\right.$, where $y=46 \cdot 8 x+11 \cdot 15)$ concentrations in all fetuses irrespective of treatment or gestational age. Reference sample is adipose tissue sampled from a 4-hour-old lamb born vaginally.

tissue-specific UCP1 protein but not UCP1 mRNA or GDP binding to UCP1 in adipose tissue mitochondria. Abundance of UCP1 protein increased with gestational age in parallel with the rise in plasma cortisol towards term. When this prepartum increase in cortisol was prevented by fetal adrenalectomy, the rise in UCP1 protein abundance towards term was abolished. Conversely, raising cortisol levels at a time when concentrations are normally low, increased UCP1 protein abundance to values similar to those seen in older animals close to term. Cortisol, therefore, appears to enhance UCP1 protein synthesis in ovine adipose tissue during late gestation. This effect appeared to be specific and not a global response of mitochondrial proteins to cortisol as VDAC, located on the outer mitochondrial membrane, showed no change in abundance during manipulation of the fetal cortisol level. The positive correlation we also observed between the plasma cortisol concentration in utero and UCP1 protein abundance strongly indicates that cortisol is a physiological regulator of UCP1 protein abundance and suggests that it may enhance the capacity for thermogenesis in preparation for cold exposure at birth.

The extent to which the effects of cortisol on UCP1 protein abundance are direct or mediated via other hormone systems remains unclear. The changes in UCP1 protein abundance did not appear to depend on leptin expression in perirenal adipose tissue. Leptin mRNA abundance was unaffected by gestational age or by manipulation of fetal plasma cortisol in the current study. Glucocorticoids have been shown to stimulate leptin gene expression in adult adipocytes in vitro (Russel et al. 1998) and to increase circulating leptin concentrations in vivo in both adult mice and human subjects (Masuzaki et al. 1997, Arvaniti et al. 1998). In fetal sheep, plasma leptin concentrations increased transiently $24-48 \mathrm{~h}$ after the onset of fetal cortisol infusion but were normal on the fifth day of infusion at the time when perirenal adipose tissue was collected in the present study (Forhead et al. 2002). In previous studies of fetal sheep, both increases and decreases in leptin expression have been observed in perirenal adipose tissue over the same period of late gestation examined in the present study (Yuen et al. 1999, Devasker et al. 2002). This may be explained, in part, by breed differences in leptin expression (Dandrea 2001) but may also reflect differences in nutritional intake by the ewes between early to mid gestation, when a reduction in maternal food intake results in increased leptin mRNA in fetal adipose tissue as measured near to term (Symonds et al. 2002).

There were also no changes in PRLR protein abundance in perirenal adipose tissue in response to fetal cortisol administration in the present study. This contrasts with earlier findings which showed cortisol-dependent upregulation of PRLR mRNA expression in fetal ovine liver (Phillips et al. 1997). However, fetal adrenalectomy did lower abundance of the long form of PRLR in perirenal adipose tissue during late gestation. While these observations suggest PRLR expression may be regulated by an adrenal medullary secretion, they provide little 
evidence for a cortisol-dependent, PRLR-mediated change in UCP1 protein abundance.

In several fetal tissues, $\mathrm{T}_{3}$ is known to mediate the maturational effects of cortisol (Fowden et al. 1998). Cortisol induces hepatic activity of the $5^{\prime}$-monodeiodinase responsible for deiodinating $T_{4}$ to $T_{3}$ and, hence, leads to a concomitant rise in fetal plasma $\mathrm{T}_{3}$ (Liggins 1994, Clarke et al. 1997a). A positive correlation between fetal plasma $\mathrm{T}_{3}$ concentration and fetal cortisol levels is therefore in accord with previous studies (Fraser \& Liggins 1989, Wallace et al. 1995). Fetal plasma $T_{3}$ was also positively correlated to UCP1 protein concentration that was equally as important as plasma cortisol in determining UCP1 abundance in the present study. In addition, exogenous administration of $\mathrm{T}_{3}$ has been shown to upregulate mitochondrial proteins including UCP1 in fetal and newborn animals (Schermer et al. 1996, Symonds et al. 2000). However, even close to term, plasma $\mathrm{T}_{3}$ levels were lower in the fetus than seen immediately after birth (Clarke $e t$ al. 1997c). The main effects of $T_{3}$ on UCP1 protein abundance may, therefore, occur after delivery. At the molecular level, the effects of $\mathrm{T}_{3}$ and/or cortisol appear to be on translation rather than on transcription of the UCP1 gene as the ontogenic and cortisol-induced changes in UCP1 protein abundance occurred in the absence of any differences in UCP1 mRNA.

The actions of cortisol on UCP1 abundance in fetal adipose tissue are in keeping with its other known maturational effects in utero (Fowden et al. 1998). At birth, the neonate must be able to maintain its core temperature by rapidly producing heat if it is to survive cold exposure. By stimulating UCP1 protein abundance the prepartum increase in cortisol will enhance the ability of the fetus to produce heat by non-shivering thermogenesis (Clarke et al. 1997c). However, even close to term, levels of UCP1 were only $40-60 \%$ of those found postnatally. Factors other than cortisol, such as noradrenaline, are involved in upregulating UCP1 availability during the perinatal period (Symonds et al. 2000). Indeed, the thermogenic potential of fetal adipose tissue, measured as GDP binding, was not affected by manipulation of the fetal cortisol level in the present study. This may reflect the lack of fetal lipolysis in utero as GDP binding to UCP1 has been shown to depend on a rise in non-esterified fatty acid release by the adipocytes (Cannon \& Nedergaard 1985). In fetal sheep, free fatty acid levels remain low during both endogenous and exogenous changes in fetal plasma cortisol (A L Fowden, unpublished observations) but rise rapidly immediately after birth when sympathetic activation of the adipocytes is maximal (Ball et al. 1992) and the inhibitory actions of the placental prostaglandins on fetal lipolysis are lost (Gunn \& Gluckman 1995). Hence, there is a cortisol-dependent increase in UCP1 before birth but no actual increase in heat production until the GDP-binding sites on UCP1 are unmasking by the events of birth itself.
In conclusion, an intact adrenal is necessary for the appearance of fetal brown adipose tissue as characterised by the late gestation rise in UCP1 protein abundance. In contrast, cortisol does not appear to have a major stimulatory role in promoting white adipose tissue characteristics as cortisol status had no effect on leptin expression in fetal adipose tissue. It remains to be established whether the observed effects on UCP1 protein are directly regulated by cortisol alone or mediated by other anabolic fetal hormones such as $\mathrm{T}_{3}$.

\section{Acknowledgements}

This work was funded in part by the Royal Society. A M was funded by a University of Nottingham Postgraduate Scholarship, S P by a Biotechnology and Biological Sciences Research Council Studentship and ME by a Physiological Society Vacation Scholarship.

\section{References}

Arvaniti K, Ricquier D, Champigny O \& Richard D 1998 Leptin and corticosterone have opposite effects on food intake and the expression of UCP1 mRNA in brown adipose tissue of lep $p^{o b} / l e p^{o b}$ mice. Endocrinology 139 4000-4003.

Ball KT, Power GG, Gunn TR, Johnston BM \& Gluckman PD 1992 Modulation of growth hormone secretion by thermogenically derived free fatty acids in the perinatal lamb. Endocrinology 131 337-343.

Bispham JR, Heasman L, Clarke L, Ingleton PM, Stephenson T \& Symonds ME 1999 Effect of maternal dexamethasone treatment and ambient temperature on prolactin receptor abundance in brown adipose and hepatic tissue in the fetus and newborn lamb. Journal of Neuroendocrinology 11 849-856.

Bispham J, Budge H, Mostyn A, Dandrea J, Clarke L, Keisler D, Symonds ME \& Stephenson T 2002 Ambient temperature, maternal dexamethasone, and postnatal ontogeny of leptin in the neonatal lamb. Pediatric Research 52 85-90.

Budge H, Bispham J, Dandrea J, Evans L, Heasman L, Ingleton P, Sullivan C, Wilson V, Stephenson T \& Symonds ME 2000 Effect of maternal nutrition on brown adipose tissue and prolactin receptor status in the fetal lamb. Pediatric Research 47 781-786.

Budge H, Mostyn A, Wilson V, Khong A, Walker AM, Symonds ME \& Stephenson T 2002 The effect of maternal prolactin infusion during pregnancy on fetal adipose tissue development. Journal of Endocrinology 147 427-433.

Cannon B \& Nedergaard J 1985 The biochemistry of an inefficient brown adipose tissue. Essays in Biochemistry 20 110-164.

Clarke L, Bryant MJ, Lomax MA \& Symonds ME 1997a Maternal manipulation of brown adipose tissue and liver development in the ovine fetus during late gestation. British Journal of Nutrition 77 871-883.

Clarke L, Buss DS, Juniper DS, Lomax MA \& Symonds ME 19976 Adipose tissue development during early postnatal life in ewe-reared lambs. Experimental Physiology 82 1015-1017.

Clarke L, Heasman L, Firth K \& Symonds ME 1997c Influence of route of delivery and ambient temperature on thermoregulation in newborn lambs. American Journal of Physiology 272 R1931-R1939.

Clarke L, Heasman L \& Symonds ME 1998 Influence of maternal dexamethasone administration on thermoregulation in lambs delivered by caesarean section. Journal of Endocrinology 156 307-314. 
Dandrea J 2001 The effect of maternal nutrition on placental and fetal development in the sheep. PhD Thesis. The University of Nottingham.

Devasker SU, Anthony RV \& Hay WW 2002 Ontogeny and insulin regulation of fetal ovine white adipose tissue leptin expression. American Journal of Physiology 282 R431-R438.

Evens Y, Yuen BS, McMillen IC, Pearce S, Owens PC, Keisler D, Stephenson T \& Symonds ME 2001 Effect of intravenous infusion of recombinant ovine leptin on uncoupling protein (UCP)-1 abundance in perirenal adipose tissue in the late gestation sheep fetus. Endocrine Abstracts 2 P24.

Forhead AJ, Thomas L, Crabtree J, Hoggard N, Gardner DS, Giussani DA \& Fowden AL 2002 Plasma leptin concentrations in fetal sheep during late gestation: ontogeny and effect of glucocorticoids. Endocrinology 275 1166-1173.

Fowden AL, Mijovic J \& Silver M 1983 The effects of cortisol on hepatic and renal gluconeogenic enzyme activities during late gestation. Journal of Endocrinology 74 703-714.

Fowden AL, Szemere J, Hughes P, Gilmour RS \& Forhead AJ 1996 The effects of cortisol on the growth rate of the sheep fetus during late gestation. Journal of Endocrinology 151 97-105.

Fowden AL, Li J \& Forhead AJ 1998 Glucocorticoids and the preparation for life after birth: are there long-term consequences of the life insurance? Proceedings of the Nutrition Society $\mathbf{5 7}$ 113-122.

Fraser M \& Liggins GC 1989 The effect of cortisol on thyroid hormone kinetics in the ovine fetus. Journal of Developmental Physiology 11 207-211.

Gottlieb RA 2000 Mitochondria: execution central. FEBS Letters 482 $6-12$.

Gunn T \& Gluckman PD 1995 Perinatal thermogenesis. Early Human Development 42 169-183.

Liggins GC 1994 The role of cortisol in preparing the fetus for birth. Reproduction, Fertility and Development 6 141-150.

Lowry OH, Rosenbrough NJ, Farr AL \& Randall RJ 1951 Protein measurement with the Folin phenol reagent. Journal of Biological Chemistry 193 265-275.

Masuzaki H, Ogawa Y, Hosoda K, Miyawaki T, Hanaoka I, Hiraoka J, Yasuno A, Nishimura H, Yoshimasa Y, Nishsi S \& Nakao K 1997 Glucocorticoid regulation of leptin synthesis and secretion in humans: elevated plasma leptin levels in Cushing's syndrome. Journal of Clinical Endocrinology and Metabolism 82 2542-2547.

Mostyn A, Stephenson T \& Symonds ME 2001 Postnatal ontogeny of cytochrome $\mathrm{c}$, the voltage dependent anion channel (VDAC) and uncoupling protein 1 (UCP1) in ovine brown adipose tissue (BAT). Proceedings of the Nutrition Society 60 OCB 187A.

Mostyn A, Bispham J, Pearce S, Evens Y, Raver N, Keisler DH, Webb R, Stephenson T \& Symonds ME 2002 Differential effects of leptin on thermoregulation and uncoupling protein abundance in the neonatal lamb. FASEB Journal 16 1438-1440.

Nevalainen M, Valve EM, Ingleton PM \& Harkonen PL 1996 Expression and hormone regulation of prolactin receptors in rat dorsal and lateral prostate. Endocrinology 137 3078-3088.

Phillips ID, Anthony RV, Butler TG, Ross JT \& McMillen IC 1997 Hepatic prolactin receptor gene expression increases in the sheep fetus before birth and after cortisol infusion. Endocrinology 138 1351-1354.

Robinson PM, Comline RS, Fowden AL \& Silver M 1983 Adrenal cortex of fetal lamb: changes after hypophysectomy and effects of synacthen on cytoarchitecture and secretory activity. Quarterly Journal of Experimental Physiology 68 15-27.

Russel CD, Petersen RN, Rao SP, Ricci MR, Prasad A, Zhang Y, Brolin RE \& Fried SK 1998 Leptin expression in adipose tissue from obese humans: depot specific regulation by insulin and dexamethasone. American Journal of Physiology 275 E507-E515.

Schermer SJ, Bird JA, Lomax MA, Shepherd DAL \& Symonds ME 1996 Effect of fetal thyroidectomy on brown adipose tissue and thermoregulation in newborn lambs. Reproduction Fertility and Development 8 995-1002.

Symonds ME, Andrews DC \& Johnson PJ 1989 The control of thermoregulation in the developing lamb during slow wave sleep. Journal of Developmental Physiology 11 289-298.

Symonds ME, Bryant MJ, Clarke L, Darby CJ \& Lomax MA 1992 Effect of maternal cold exposure on brown adipose tissue and thermogenesis in the neonatal lamb. Journal of Physiology $\mathbf{4 5 5}$ 487-502.

Symonds ME, Bird JA, Sullivan C, Wilson V, Clarke L \& Stephenson T 2000 Effect of delivery temperature on endocrine stimulation of thermoregulation in lambs born by cesarean section. Journal of Applied Physiology 88 47-53.

Symonds ME, Gopalakrishnan G, Bispham JB, Pearce S, Dandrea J, Mostyn A, Ramsay MM \& Stephenson T 2002 Maternal nutrient restriction during placental growth, programming of fetal adiposity and juvenile blood pressure control. Archives of Physiology and Biochemistry (In Press).

Wallace MJ, Hooper SB \& Harding R 1995 Effects of elevated fetal cortisol secretion on the volume, secretion, and reabsorption of lung fluid. American Journal of Physiology 269 R881-R887.

Yuen BSJ, McMillen IC, Symonds ME \& Owens PC 1999 Abundance of leptin messenger ribonucleic acid in fetal adipose tissue is related to fetal body weight. Journal of Endocrinology 163 R1-R4.

Received 1 October 2002

Accepted 7 October 2002 